\title{
Klasifikasi Sampah Daur Ulang Menggunakan Support Vector Machine DENGAN Fitur Local Binary Pattern
}

\author{
${ }^{1}$ Leonardo, ${ }^{2}$ Yohannes, ${ }^{3}$ Ery Hartati \\ STMIK GI MDP, Jalan Rajawali No. 14 Palembang, 0711-376400 \\ Jurusan Teknik Informatika, STMIK MDP, Palembang \\ e-mail: ${ }^{1}$ leolikeyou1@mhs.mdp.ac.id, ${ }^{2}$ yohannesmasterous@mdp.ac.id, \\ ery_hartati@mdp.ac.id,
}

\begin{abstract}
Abstrak
Sampah merupakan salah satu masalah yang selalu muncul di Negara Indonesia bahkan di dunia. Semakin lama semakin meningkat produksi sampah yang dihasilkan seiring dengan bertambahnya penduduk dan konsumsi masyarakat. Maka dari itu dibutuhkan pencegahan untuk tidak terlalu banyak membuang atau memproduksi sampah sembarangan dengan cara dikelola atau didaur ulang. Pada penelitian ini, klasifikasi sampah daur ulang dilakukan untuk lima jenis, yaitu cardboard, glass, metal, paper dan plastic menggunakan metode ekstraksi fitur tekstur Local Binary Pattern (LBP) dan Support Vector Machine (SVM) sebagai metode klasifikasi. Untuk teknik pengujian dan pembagian dataset menggunakan metode K-Fold Cross Validation jenis Leave One Out (LOO). Dari hasil pengujian yang telah dilakukan menggunakan fold 5 sampai fold 10. Kernel polynomial memperoleh hasil accuracy tertinggi dari setiap fold yang digunakan dengan nilai rata-rata 87,82\%. Berdasarkan hasil pengujian klasifikasi SVM baik kernel linear, polynomial maupun gaussian dengan memakai fold 5 sampai fold 10. Accuracy terbaik jenis sampah cardboard senilai 96,01\%. Untuk jenis sampah glass, accuracy terbaik didapat senilai 90,62\%. Selanjutnya jenis sampah metal mendapatkan nilai accuracy terbaik 89,72\%. Kemudian jenis sampah paper nilai accuracy tertinggi sebesar 96,01\%. Serta jenis sampah plastic yang memperoleh nilai accuracy tertinggi $87,64 \%$.
\end{abstract}

Kata kunci : Sampah, Local Binary Pattern, K-Fold Cross Validation, Fold, Support Vector Machine, LBP, SVM

\begin{abstract}
Garbage is one of the problems that always arise in Indonesia and even in the world. Increasingly, the production of waste is increased along with the increase in population and consumption. Therefore, need a prevention to stop wasting or producing garbage through recycle. This research do garbage recycle classification of cardboard, glass, metal, paper and plastic by using Local Binary Pattern (LBP) texture feature extraction methode and Support Vector Machine (SVM) as classification methode. For examination technic and dataset distribution is using K-Fold Cross Validation methode type Leave One Out (LOO). From examination result had been done were using fold 5 until fold 10. Polynomial kernel get highest accuracy result from every fold used with mean point $87.82 \%$. Based on SVM classification examination result whether linear kernel, polynomial nor gaussian by using fold 5 until fold 10. The best accuracy point for cardboard garbage is $96.01 \%$. For glass garbage, the best accuracy point is $90.62 \%$. Then, metal garbage get the best accuracy point $89.72 \%$. While paper garbage with highest accuracy point $96.01 \%$. And plastic garbage with highest accuracy point $87.64 \%$.
\end{abstract}

Keywords : Garbage, Local Binary Pattern, K-Fold Cross Validation, Fold, Support Vector Machine, LBP, SVM 
Vol. 1, No. 1, Oktober 2020, Hal. 78 - 89

\section{PENDAHULUAN}

$\mathrm{S}$ ampah merupakan salah satu masalah yang selalu muncul di Negara Indonesia bahkan didunia. Semakin lama semakin meningkat produksi sampah yang dihasilkan seiring dengan bertambahnya penduduk dan konsumsi masyarakat [1]. Sampah non organik merupakan sampah yang sulit terurai dalam jangka waktu pendek. Sehingga pada sampah non organik perlu dilakukan daur ulang. Daur ulang adalah proses bahan yang tidak berguna menjadi bahan baru yang ada nilai jualnya.

Daur ulang menjadi pilihan yang tepat mengingat sampah yang dihasilkan semakin banyak. Daur ulang dilakukan dengan tujuan mengurangi konsumsi bahan baku, menghemat penggunaan energi, mengurangi polusi lingkungan, kerusakan lahan ekosistem dan mencegah efek rumah kaca. Daur ulang dapat memanfaatkan kembali material yang terbuang dari berbagai macam sampah. Seperti sampah kardus, plastik, kertas, logam dan kaca merupakan bahan yang dapat didaur ulang untuk memperoleh barang olahan yang baru. Selain itu daur ulang juga menghasilkan keuntungan yang bisa memberikan ekonomi menjadi baik [17].

Terdapat beberapa penelitian terdahulu yang berkaitan dengan jenis sampah daur ulang. Seperti penelitian yang dilakukan tentang klasifikasi dataset trashnet menggunakan model deep learning. Dataset trashnet merupakan kumpulan data sampah daur ulang yang terbagi menjadi beberapa kelas. Seperti sampah jenis kertas, kaca, logam, plastik dan kardus. Pada penelitian ini jumlah dataset yang digunakan sekitar 2390 citra yang masing-masing jenis terdiri dari 500-400 citra. Setelah itu data masing-masing kelas dibagi dengan 70\% digunakan untuk data latih, $17 \%$ untuk data uji serta $13 \%$ untuk validasi data kemudian baru diklasifikasi. Hasil yang diperoleh dari penelitian ini dengan metode convolutional neural network lebih dari $76 \%$ akurasi pada klasifikasi sampah daur ulang [3]. Kemudian ada penelitian pengenalan kerusakan kertas dengan menggunakan metode support vector machine (SVM). Menerapkan model multiclass SVM untuk klasifikasi, kemudian SVM dilatih untuk menghasilkan objek sampel pelatihan serta di uji untuk memprediksi sampel melalui pencocokan objek. Setelah itu baru memproses klasifikasi kerusakan kertas. Hasil dari penelitian menunjukkan bahwa sistem SVM menghasilkan kecepatan pengenalan yang lebih cepat dengan tingkat pengenalan yang baik [11]. Menurut [17] yang melakukan penelitian tentang klasifikasi sampah daur ulang menggunakan metode support vector machine (SVM) dengan fitur scale-invariant feature transform (SIFT) dan convolutional neural network (CNN). Dengan menggunakan dataset berisi citra sampah yang dapat daur ulang dibagi menjadi enam kelas masing-masing sekitar 400-500 citra. Hasil penelitian menunjukkan bahwa SVM berkinerja lebih baik dari CNN yang tentunya telah membuka jalan untuk meningkatkan akurasi dan ketepatan klasifikasi sampah daur ulang.

Selanjutnya penelitian terdahulu mengenai local binary pattern (LBP) yaitu [8] telah melakukan penelitian pengenalan wajah dengan LBP sebagai ekstraksi fitur serta algoritma frequent growth. Hasil dari penelitannya menunjukkan bahwa algoritma dapat mengekstraksi lebih baik untuk pengenalan wajah secara efektif. Penelitian lainnya dilakukan oleh [5] yang melakukan penelitian mengenai perluasan skala dan orientasi rotasi menggunakan fitur LBP. LBP telah teruji dalam berbagai skenario klasifikasi tekstur dan memberikan fitur yang sangat diskriminatif. Hasil dari percobaan terbukti bahwa LBP mudah diterapkan dan memberikan skala yang kuat serta representasi fitur invariant rotasi yang baik. Kemudian penelitian yang dilakukan [4] sistem deteksi mata uang kertas berdasarkan fitur gabungan speeded up robust feature (SURF) dan local binary pattern (LBP) dengan menggunakan klasifikasi support vector machine (SVM). Pada tahap awal citra di preprocessing terlebih dahulu guna menghasilkan kualitas yang baik setelah itu dilakukan ekstraksi fitur gabungan menggunakan SURF dan LBP kemudian baru diklasifikasi SVM. SVM tergolong sebagai metode klasifikasi yang berkinerja baik dalam hal prediksi dengan mengeksplorasi data dan mengenali pola. Terbukti dengan hasil penelitian dari klasifikasi SVM dengan gabungan fitur SURF dan LBP yang mampu mendeteksi mata uang kertas dengan akurasi $92,6 \%$ meskipun posisinya dirotasi tetap mampu dikenali.

Leonardo, et., al (Klasifikasi Sampah Daur Ulang Menggunakan Support Vector Machine Dengan Fitur Local Binary Pattern) 
Tentunya dari hasil penelitian ini dapat membuka jalan untuk pengenalan menggunakan metode klasifikasi SVM dengan fitur LBP.

\section{METODE PENELITIAN}

Berikut ini adalah tahapan metodologi penelitian yang dilakukan dalam menerapakan metode support vector machine dengan fitur local binary pattern untuk klasifikasi sampah daur ulang.

\subsection{Identifikasi Masalah}

Penelitian dilanjutkan dengan mencari jurnal, buku dan hasil penelitan lain yang terkait dengan metode ekstraksi fitur Local Binary Pattern (LBP) dan klasifikasi Support Vector Machine (SVM). Tahapan ini ditujukan untuk mengumpulkan referensi yang relevan sehingga penelitian ini dapat memberikan kontribusi penelitian yang baru dan memiliki dasar yang kuat.

\subsection{Studi Literatur}

Mempelajari referensi yang relevan terhadap penelitian seperti pemaparan metode contrast stretching dan histogram equalization untuk memperbaiki kualitas citra digital.

\subsection{Pengumpulan Data}

Analisis dan desain dilakukan dengan mengumpulkan dataset TrashNet yang diambil dari https://github.com/garythung/trashnet. Ekstensi dari citra sampah yang digunakan adalah JPG dengan ukuran $512 \times 384$ piksel. Klasifikasi dibagi menjadi 5 yaitu kardus, kaca, logam, kertas dan plastik. Dataset akan dibagi menjadi dua bagian yaitu dataset training dan dataset testing. Pembagian dataset menggunakan metode K-Fold Cross Validation dengan jenis leave-one out. Jenis dan jumlah pada dataset dapat dilihat pada Tabel 1.

Tabel 1. Detail dan Gambar Dataset Sampah

\begin{tabular}{|c|c|c|c|}
\hline No & Jenis Sampah & Citra Sampah Daur Ulang & Jumlah Citra \\
\hline 1. & Kardus & & \\
& & \\
\hline 2. & Kaca & \\
\hline
\end{tabular}

Leonardo, et., al (Klasifikasi Sampah Daur Ulang Menggunakan Support Vector Machine Dengan Fitur Local Binary Pattern) 
Vol. 1, No. 1, Oktober 2020, Hal. 78 - 89

\begin{tabular}{|c|c|c|c|}
\hline No & Jenis Sampah & Citra Sampah Daur Ulang & Jumlah Citra \\
\hline 3. & Logam & & \\
& & & \\
\hline 4. & Kertas & & \\
& & & \\
\hline 5. & Plastik & & \\
& & & \\
& & & \\
& & & \\
\hline
\end{tabular}

\subsection{Proses Penelitian}

Proses penelitian dimulai dengan mengumpulkan dataset sampah daur ulang. Selanjutnya dataset dilakukan ekstraksi ciri berdasarkan tekstur menggunakan Local Binary Pattern (LBP) dilanjutkan dengan pengujian dan pembagian dataset $K$-Fold Cross Validation jenis Leave One Out (LOO) untuk menentukan data testing dan data training. Setelah pembagian data testing dan data training. Data training lanjut ke proses klasifikasi menggunakan metode Support Vector Machine (SVM) yang digunakan untuk klasifikasi sampah daur ulang. Data training yang sudah melalui proses klasifikasi SVM mendapatkan model dari data training citra jenis sampah daur ulang. Selanjutnya pada bagian data testing yang telah melalui proses ekstraksi fitur LBP dengan pengujian $K$-Fold Cross Validation akan mendapatkan model dari data testing citra jenis sampah daur ulang. Kemudian proses terakhir membandingkan model yang didapat dari proses data training dengan data testing. Untuk proses tahapan penelitian dapat dilihat pada Gambar 1. 




Gambar 1. Tahapan Penelitian

Berdasarkan Gambar 1 pada tahapan penelitian ada proses ekstraksi fitur Local Binary Pattern, pengujian K-Fold Cross Validation dan klasifikasi Support Vector Machine, berikut penjelasannya :

\section{Local Binary Pattern}

LBP adalah iluminasi tekstur invariant yang kuat. Histogram dari pola biner yang dihitung pada suatu wilayah adalah digunakan untuk deskripsi tekstur. Operator menjelaskan setiap piksel dengan tingkat abu-abu relatif dari piksel tetangganya. Itu deskriptor menggambarkan hasil atas lingkungan sebagai angka biner [6]. Menurut [2] Local Binary Pattern (LBP) adalah operator yang digunakan untuk menggambarkan fitur tekstur lokal dari suatu citra. Keuntungan Local Binary Pattern (LBP) adalah kemudahan implementasi dalam menangani rotasi objek dan citra abu-abu. Berikut bagan proses LBP yang dapat dilihat pada Gambar 2.

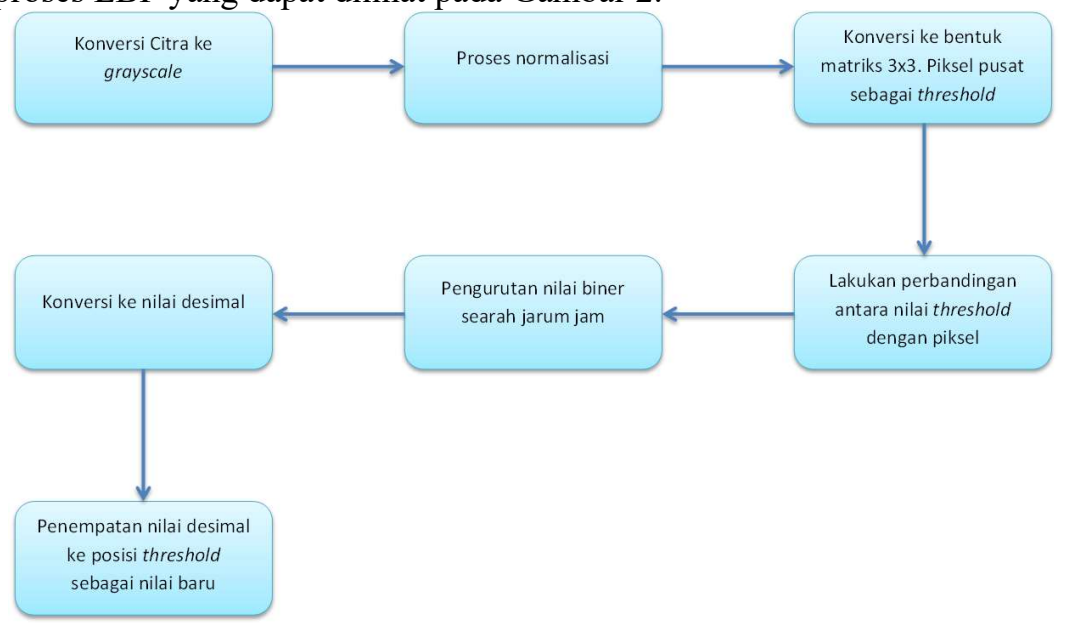

Gambar 2. Bagan proses LBP

Leonardo, et., al (Klasifikasi Sampah Daur Ulang Menggunakan Support Vector Machine Dengan Fitur Local Binary Pattern) 


\section{K-Fold Cross Validation}

K-Fold Cross Validation merupakan metode untuk pengujian data yang dibagi partisi secara sama ke dalam persamaan $\mathrm{k}$ yang mendekati persamaan segmen atau folds. Pada partisi folds ini, data latih dan data uji dilakukan iterasi $\mathrm{k}$ dengan begitu setiap iterasi akan meninggalkan satu fold untuk data uji sedangkan untuk data latih sisa dari k-1 folds. Kemudian nilai yang didapat dari setiap iterasi akan di rata-rata untuk mendapatkan akurasi model. Hal penting yang perlu dicatat bahwa data pada umumnya di stratifikasi sebelum dibagi ke dalam segmen k. Stratifikasi adalah proses menyusun ulang data ke dalam suatu cara tertentu yang mana setiap fold merepresentasikan dengan baik secara keseluruhan [16].

Menurut [14] K-Fold Cross Validation memiliki beberapa jenis salah satunya leave-one out cross. Validasi leave-one out cross adalah kasus khusus dari validasi $K$ Fold Cross yang mana jumlah folds sama dengan jumlah instans. Ketika jumlah instans pada dataset nilai kelas kecil, semacam gen microarray data dan gen sequence data. Leave-one out harus diadopsi untuk mendapatkan estimasi keakuratan yang terpecaya dari klasifikasi. Beberapa studi yang mengadopsi validasi leave-one out cross untuk mengevaluasi performa dari penggolongan metode klasifikasi ketika jumlah instans kedalam data training dan testing tidak ada, poin estimasi keakuratan untuk data yang diberikan adalah konstan. Hal ini tentunya akan memperoleh distribusi sampel untuk validasi leave-one out cross untuk membuat inferensi statistic tentang rata-rata akurasi dari penggolongan metode klasifikasi.

\section{Support Vector Machine}

Support Vector Machine (SVM) adalah metode pembelajaran mesin yang diawasi yang dapat digunakan untuk tantangan klasifikasi atau regresi, namun sebagian besar digunakan dalam masalah klasifikasi dengan dukungan metode ekstraksi fitur [13]. Tujuan Support Vector Machine (SVM) adalah untuk menghasilkan model yang memprediksi nilai target contoh data dalam set pengujian yang hanya diberikan atribut. Support Vector Machine (SVM) adalah metode pembelajaran terawasi yang dikembangkan oleh vapnik yang digunakan untuk klasifikasi dan analisis regresi, Support Vector Machine (SVM) bekerja pada teori pembelajaran statistic dan dapat menghasilkan hasil yang kuat, akurat dan efektif dengan lebih sedikit sampel pelatihan [9].

SVM dapat digunakan untuk menyelesaikan masalah klasifikasi dan regresi. Ini adalah teknik pembelajaran mesin dan itu dianggap salah satu metode klasifikasi terbaik. Dengan metode ini, item data diplot sebagai titik tertentu dalam ruang ndimensi terhadap nilai fitur dari koordinat tertentu. Item dalam SVM diklasifikasikan berdasarkan pemisahan hyperplane untuk masing-masing dari data multidimensi dengan menemukan hyperplane yang jarak minimumnya lebih besar untuk data latih [1].

Metode klasifikasi SVM multiclass berdasarkan pada klasifikasi biner atau direduksi menggunakan seperangkat biner yang dilatih untuk memisahkan berbagai kelompok objek satu sama lain. Dalam klasifikasi terdapat beberapa skema dalam menentukan suatu objek. Maka dari itu klasifikasi SVM multiclass dapat digunakan dalam memecahkan masalah klasifikasi menggunakan pendekatan penguraian masalah biner dengan cara satu lawan semua dan satu lawan satu. Cara satu lawan semua mengkontruksikan jumlah kelas dilatih yakni semua data latih untuk memisahkan dari kelas yang tersisa. Sementara cara satu lawan satu yakni klasifikasi SVM berpasangan yakni menentukan keputusan untuk semua kombinasi pasangan kelas. Dengan demikian, cara satu lawan satu dianggap lebih praktis[7].

Leonardo, et., al (Klasifikasi Sampah Daur Ulang Menggunakan Support Vector Machine Dengan Fitur Local Binary Pattern) 


\subsection{Implementasi}

Setelah proses penelitian maka dilakukan tahapan implementasi ke dalam tahap coding program. Dataset yang telah ada akan diekstraksi fitur berdasarkan tekstur menggunakan Local Binary Pattern. Selanjutnya citra dilakukan pengujian dan pembagian data menjadi data training dan data testing menggunakan $K$-Fold Cross Validation jenis Leave One Out. Fold yang digunakan yaitu 5-Fold, 6-Fold, 7-Fold, 8-Fold, 9-Fold dan 10-Fold. Kemudian proses mengklasifikasi dengan Support Vector Machine untuk mendapatkan hasilnya.

\subsection{Pengujian}

Kemudian pada tahap pengujian dimana dataset yang dikumpulkan akan dibagi secara partisi menggunakan metode $K$-Fold cross validation jenis leave-one out (LOO). Menurut [15] pada K-Fold cross validation biasanya ditetapkan fold yang digunakan yakni 5-Fold hingga 10-Fold. [10] menyebutkan bahwa penggunaan fold terbaik untuk validitas yakni 10-fold hal ini dikarenakan semakin besar fold yang digunakan maka akan semakin baik kinerja model klasifikasi suatu sistem.

Fold yang digunakan dalam pengujian ini dimulai dari 5-Fold, 6-Fold, 7-Fold, 8-Fold, 9-Fold dan 10-Fold. Dimana pada setiap fold akan ada 1 fold yang digunakan untuk data training dan sisanya untuk data testing. Kemudian data akan diklasifikasi menggunakan metode SVM multiclass. Untuk contoh skema penggunaan K-Fold Cross Validation dalam 5-Fold dapat dilihat pada Gambar 2 dengan jumlah data training dan data testing yang digunakan pada setiap skema fold diperlihatkan pada Tabel 2 .

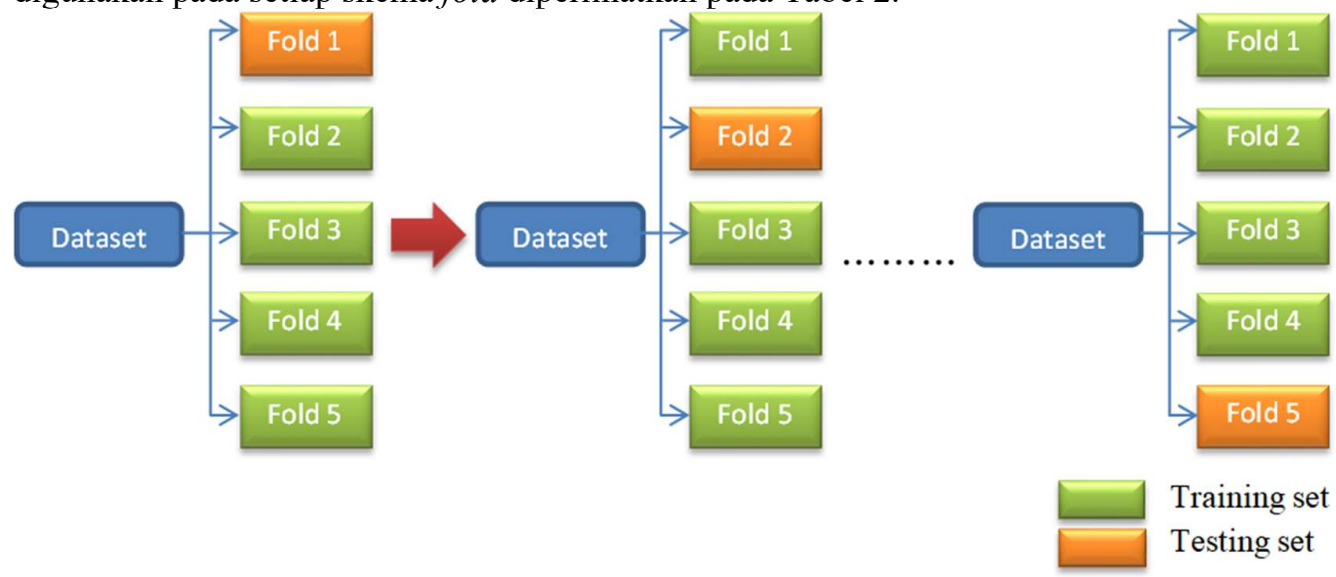

Gambar 2. Skema 5 K-Fold cross validation

Tabel 2. Jumlah Data yang Digunakan

\begin{tabular}{|l|l|c|c|}
\hline No & Pengunaan Fold & Jumlah Data Training & Jumlah Data Testing \\
\hline 1 & 5-Fold & 1611 citra & 404 citra \\
\hline 2 & 6-Fold & 1679 citra & 336 citra \\
\hline 3 & 7-Fold & 1727 citra & 288 citra \\
\hline 4 & 8-Fold & 1762 citra & 253 citra \\
\hline 5 & 9-Fold & 1791 citra & 224 citra \\
\hline 6 & 10-Fold & 1811 citra & 204 citra \\
\hline
\end{tabular}

Selanjutnya tahap pengujian dimana proses ekstraksi fitur LBP dengan pengujian $K$ Fold cross validation dan klasifikasi SVM akan dihitung dalam bentuk Confusion Matrix.

Leonardo, et., al (Klasifikasi Sampah Daur Ulang Menggunakan Support Vector Machine Dengan Fitur Local Binary Pattern) 
Dengan parameter pengujian hasil yang berupa Akurasi, Presisi, dan Recall untuk mengukur kinerja suatu model yang memiliki hasil terbaik dari metode yang telah ditentukan [12].

\subsection{Pembuatan Laporan}

Pada tahap ini, setelah melakukan tahapan-tahapan dari metodologi penelitian kemudian membuat laporan penelitian yang berisi pembahasan pada setiap bab sehingga disajikan ke dalam bentuk laporan hasil penelitian yang objektif dan jelas.

\section{HASIL DAN PEMBAHASAN}

Hasil pengujian yang dilakukan pada 5 jenis sampah daur ulang yang telah diekstraksi fitur Local Binary Pattern, pengujian dan pembagian dataset training dan testing menggunakan K-Fold Cross Validation serta klasifikasi Support Vector Machine. Hasil pengujian berupa nilai pengujian masing-masing jenis sampah dengan menggunakan fold 5 sampai fold 10 serta hasil rata-rata dari keseluruhan fold.

1. Hasil Pengujian Jenis Sampah Fold 5

Pada tahap ini menjelaskan hasil klasifikasi terhadap masing-masing jenis sampah daur ulang yang telah melalui proses ekstraksi fitur LBP, cross validation LOO yang menggunakan fold 5 dan klasifikasi SVM multiclass. Klasifikasi menggunakan SVM dengan fungsi kernel linear, polynomial dan gaussian. Hasil pengujian berupa nilai accuracy, precision dan recall yang dapat dilihat pada Tabel 3.

Tabel 3. Hasil Accuracy, Precision dan Recall pada fold 5

\begin{tabular}{|c|l|c|c|c|c|c|}
\hline Parameter & Kernel & Cardboard (\%) & Glass (\%) & Metal (\%) & Paper (\%) & Plastic (\%) \\
\hline \multirow{3}{*}{ Accuracy } & Linear & $91,76 \%$ & $84,07 \%$ & $84,57 \%$ & $92,85 \%$ & $80,75 \%$ \\
\cline { 2 - 7 } & Polynomial & $92,30 \%$ & $84,97 \%$ & $85,51 \%$ & $92,85 \%$ & $82,34 \%$ \\
\cline { 2 - 7 } & Gaussian & $88,49 \%$ & $52,03 \%$ & $75,12 \%$ & $82,33 \%$ & $83,62 \%$ \\
\hline \multirow{3}{*}{ Precision } & Linear & $79,68 \%$ & $59,98 \%$ & $62,69 \%$ & $81,88 \%$ & $51,89 \%$ \\
\cline { 2 - 7 } & Polynomial & $81,21 \%$ & $62,27 \%$ & $65,58 \%$ & $80,94 \%$ & $55,72 \%$ \\
\cline { 2 - 7 } & Gaussian & $98,84 \%$ & $34,02 \%$ & $73,27 \%$ & $68,51 \%$ & $74,54 \%$ \\
\hline \multirow{3}{*}{ Recall } & Linear & $79,17 \%$ & $62,55 \%$ & $55,08 \%$ & $82,61 \%$ & $55,55 \%$ \\
\cline { 2 - 7 } & Polynomial & $80,16 \%$ & $64,28 \%$ & $58,07 \%$ & $84,38 \%$ & $58,02 \%$ \\
\cline { 2 - 7 } & Gaussian & $42,96 \%$ & $79,00 \%$ & $27,44 \%$ & $22,34 \%$ & $32,52 \%$ \\
\hline
\end{tabular}

2. Hasil Pengujian Jenis Sampah Fold 6

Pada tahap ini menjelaskan hasil klasifikasi terhadap masing-masing jenis sampah daur ulang yang telah melalui proses ekstraksi fitur LBP, cross validation LOO yang menggunakan fold 6 dan klasifikasi SVM multiclass. Klasifikasi menggunakan SVM dengan fungsi kernel linear, polynomial dan gaussian. Hasil pengujian berupa nilai accuracy, precision dan recall yang dapat dilihat pada Tabel 4.

Tabel 4. Hasil Accuracy, Precision dan Recall pada fold 6

\begin{tabular}{|c|l|c|c|c|c|c|}
\hline Parameter & Kernel & Cardboard (\%) & Glass (\%) & Metal (\%) & Paper (\%) & Plastic (\%) \\
\hline \multirow{3}{*}{ Accuracy } & Linear & $92,01 \%$ & $83,33 \%$ & $84,17 \%$ & $92,80 \%$ & $81,29 \%$ \\
\cline { 2 - 7 } & Polynomial & $89,67 \%$ & $82,62 \%$ & $80,87 \%$ & $92,95 \%$ & $75,89 \%$ \\
\cline { 2 - 7 } & Gaussian & $88,49 \%$ & $52,95 \%$ & $74,99 \%$ & $83,28 \%$ & $84,37 \%$ \\
\hline \multirow{3}{*}{ Precision } & Linear & $80,09 \%$ & $58,15 \%$ & $62,03 \%$ & $81,90 \%$ & $53,12 \%$ \\
\cline { 2 - 7 } & Polynomial & $82,44 \%$ & $69,43 \%$ & $69,85 \%$ & $86,75 \%$ & $60,30 \%$ \\
\cline { 2 - 7 } & Gaussian & $98,90 \%$ & $36,07 \%$ & $74,61 \%$ & $67,91 \%$ & $78,99 \%$ \\
\hline \multirow{3}{*}{ Recall } & Linear & $79,89 \%$ & $61,30 \%$ & $54,84 \%$ & $82,62 \%$ & $55,35 \%$ \\
\cline { 2 - 7 } & Polynomial & $81,21 \%$ & $64,41 \%$ & $57,31 \%$ & $81,20 \%$ & $61,66 \%$ \\
\cline { 2 - 7 } & Gaussian & $42,92 \%$ & $82,12 \%$ & $26,10 \%$ & $28,08 \%$ & $31,07 \%$ \\
\hline
\end{tabular}

Leonardo, et., al (Klasifikasi Sampah Daur Ulang Menggunakan Support Vector Machine Dengan Fitur Local Binary Pattern) 
3. Hasil Pengujian Jenis Sampah Fold 7

Pada tahap ini menjelaskan hasil klasifikasi terhadap masing-masing jenis sampah daur ulang yang telah melalui proses ekstraksi fitur LBP, cross validation LOO yang menggunakan fold 7 dan klasifikasi SVM multiclass. Klasifikasi menggunakan SVM dengan fungsi kernel linear, polynomial dan gaussian. Hasil pengujian berupa nilai accuracy, precision dan recall yang dapat dilihat pada Tabel 5.

Tabel 5. Hasil Accuracy, Precision dan Recall pada fold 7

\begin{tabular}{|c|l|c|c|c|c|c|}
\hline Parameter & Kernel & Cardboard (\%) & Glass (\%) & Metal (\%) & Paper (\%) & Plastic (\%) \\
\hline \multirow{3}{*}{ Accuracy } & Linear & $89,95 \%$ & $79,43 \%$ & $81,19 \%$ & $91,68 \%$ & $78,86 \%$ \\
\cline { 2 - 7 } & Polynomial & $92,61 \%$ & $85,31 \%$ & $86,00 \%$ & $93,60 \%$ & $82,93 \%$ \\
\cline { 2 - 7 } & Gaussian & $88,49 \%$ & $50,44 \%$ & $82,43 \%$ & $82,58 \%$ & $78,05 \%$ \\
\hline \multirow{3}{*}{ Precision } & Linear & $82,66 \%$ & $64,44 \%$ & $68,32 \%$ & $85,61 \%$ & $61,14 \%$ \\
\cline { 2 - 7 } & Polynomial & $82,40 \%$ & $63,23 \%$ & $67,38 \%$ & $82,62 \%$ & $56,92 \%$ \\
\cline { 2 - 7 } & Gaussian & $98,90 \%$ & $34,09 \%$ & $89,52 \%$ & $68,80 \%$ & $70,67 \%$ \\
\hline \multirow{3}{*}{ Recall } & Linear & $79,11 \%$ & $59,42 \%$ & $60,95 \%$ & $82,09 \%$ & $58,22 \%$ \\
\cline { 2 - 7 } & Polynomial & $80,14 \%$ & $64,51 \%$ & $58,30 \%$ & $86,35 \%$ & $61,80 \%$ \\
\cline { 2 - 7 } & Gaussian & $42,91 \%$ & $82,97 \%$ & $13,90 \%$ & $24,07 \%$ & $41,37 \%$ \\
\hline
\end{tabular}

4. Hasil Pengujian Jenis Sampah Fold 8

Pada tahap ini menjelaskan hasil klasifikasi terhadap masing-masing jenis sampah daur ulang yang telah melalui proses ekstraksi fitur LBP, cross validation LOO yang menggunakan fold 8 dan klasifikasi SVM multiclass. Klasifikasi menggunakan SVM dengan fungsi kernel linear, polynomial dan gaussian. Hasil pengujian berupa nilai accuracy, precision dan recall yang dapat dilihat pada Tabel 6 .

Tabel 6. Hasil Accuracy, Precision dan Recall pada fold 8

\begin{tabular}{|c|l|c|c|c|c|c|}
\hline Parameter & Kernel & Cardboard (\%) & Glass (\%) & Metal (\%) & Paper (\%) & Plastic (\%) \\
\hline \multirow{3}{*}{ Accuracy } & Linear & $91,71 \%$ & $83,67 \%$ & $85,45 \%$ & $92,95 \%$ & $81,88 \%$ \\
\cline { 2 - 7 } & Polynomial & $92,06 \%$ & $85,46 \%$ & $85,65 \%$ & $92,70 \%$ & $82,78 \%$ \\
\cline { 2 - 7 } & Gaussian & $88,49 \%$ & $49,75 \%$ & $77,83 \%$ & $83,08 \%$ & $84,32 \%$ \\
\hline \multirow{3}{*}{ Precision } & Linear & $79,85 \%$ & $59,11 \%$ & $65,11 \%$ & $82,04 \%$ & $55,15 \%$ \\
\cline { 2 - 7 } & Polynomial & $80,31 \%$ & $63,48 \%$ & $67,44 \%$ & $80,83 \%$ & $56,49 \%$ \\
\cline { 2 - 7 } & Gaussian & $98,99 \%$ & $31,49 \%$ & $74,77 \%$ & $72,50 \%$ & $78,30 \%$ \\
\hline \multirow{3}{*}{ Recall } & Linear & $78,67 \%$ & $60,32 \%$ & $59,29 \%$ & $83,12 \%$ & $57,83 \%$ \\
\cline { 2 - 7 } & Polynomial & $79,88 \%$ & $64,75 \%$ & $56,32 \%$ & $83,36 \%$ & $62,26 \%$ \\
\cline { 2 - 7 } & Gaussian & $42,92 \%$ & $86,21 \%$ & $23,15 \%$ & $25,78 \%$ & $30,77 \%$ \\
\hline
\end{tabular}

5. Hasil Pengujian Jenis Sampah Fold 9

Pada tahap ini menjelaskan hasil klasifikasi terhadap masing-masing jenis sampah daur ulang yang telah melalui proses ekstraksi fitur LBP, cross validation LOO yang menggunakan fold 9 dan klasifikasi SVM multiclass. Klasifikasi menggunakan SVM dengan fungsi kernel linear, polynomial dan gaussian. Hasil pengujian berupa nilai accuracy, precision dan recall dapat dilihat pada Tabel 7.

Tabel 7. Hasil Accuracy, Precision dan Recall pada fold 9

\begin{tabular}{|c|l|c|c|c|c|c|}
\hline Parameter & Kernel & Cardboard (\%) & Glass (\%) & Metal (\%) & Paper (\%) & Plastic (\%) \\
\hline \multirow{4}{*}{ Accuracy } & Linear & $92,15 \%$ & $84,10 \%$ & $84,79 \%$ & $93,44 \%$ & $82,21 \%$ \\
\cline { 2 - 7 } & Polynomial & $92,51 \%$ & $85,76 \%$ & $86,10 \%$ & $92,56 \%$ & $83,13 \%$ \\
\cline { 2 - 7 } & Gaussian & $88,49 \%$ & $44,96 \%$ & $81,98 \%$ & $82,93 \%$ & $84,42 \%$ \\
\hline \multirow{3}{*}{ Precision } & Linear & $80,25 \%$ & $59,95 \%$ & $63,46 \%$ & $85,00 \%$ & $55,62 \%$ \\
\cline { 2 - 7 } & Polynomial & $81,68 \%$ & $64,29 \%$ & $67,49 \%$ & $80,39 \%$ & $57,99 \%$ \\
\cline { 2 - 7 } & Gaussian & $98,98 \%$ & $26,00 \%$ & $75,89 \%$ & $68,68 \%$ & $79,92 \%$ \\
\hline
\end{tabular}

Leonardo, et., al (Klasifikasi Sampah Daur Ulang Menggunakan Support Vector Machine Dengan Fitur Local Binary Pattern) 
Vol. 1, No. 1, Oktober 2020, Hal. 78 - 89

\begin{tabular}{|c|l|l|l|l|l|l|}
\hline \multirow{3}{*}{ Recall } & Linear & $80,74 \%$ & $61,08 \%$ & $57,58 \%$ & $81,89 \%$ & $60,54 \%$ \\
\cline { 2 - 7 } & Polynomial & $80,90 \%$ & $65,30 \%$ & $59,09 \%$ & $83,40 \%$ & $61,54 \%$ \\
\cline { 2 - 7 } & Gaussian & $42,96 \%$ & $94,31 \%$ & $14,66 \%$ & $25,36 \%$ & $29,72 \%$ \\
\hline
\end{tabular}

6. Hasil Pengujian Jenis Sampah Fold 10

Pada tahap ini menjelaskan hasil klasifikasi terhadap masing-masing jenis sampah daur ulang yang telah melalui proses ekstraksi fitur LBP, cross validation LOO yang menggunakan fold 10 dan klasifikasi SVM multiclass. Klasifikasi menggunakan SVM dengan fungsi kernel linear, polynomial dan gaussian. Hasil pengujian berupa nilai accuracy, precision dan recall yang dapat dilihat pada Tabel 8.

Tabel 8. Hasil Accuracy, Precision dan Recall pada fold 10

\begin{tabular}{|c|l|c|c|c|c|c|}
\hline Parameter & Kernel & Cardboard (\%) & Glass (\%) & Metal (\%) & Paper (\%) & Plastic (\%) \\
\hline \multirow{3}{*}{ Accuracy } & Linear & $92,46 \%$ & $84,32 \%$ & $85,36 \%$ & $93,54 \%$ & $82,48 \%$ \\
\cline { 2 - 7 } & Polynomial & $92,41 \%$ & $85,16 \%$ & $85,81 \%$ & $93,10 \%$ & $82,48 \%$ \\
\cline { 2 - 7 } & Gaussian & $88,54 \%$ & $44,81 \%$ & $81,84 \%$ & $82,68 \%$ & $84,22 \%$ \\
\hline \multirow{3}{*}{ Precision } & Linear & $82,10 \%$ & $60,95 \%$ & $65,36 \%$ & $83,17 \%$ & $56,18 \%$ \\
\cline { 2 - 7 } & Polynomial & $81,25 \%$ & $63,29 \%$ & $67,42 \%$ & $80,89 \%$ & $55,75 \%$ \\
\cline { 2 - 7 } & Gaussian & $98,89 \%$ & $25,89 \%$ & $75,37 \%$ & $70,41 \%$ & $77,86 \%$ \\
\hline \multirow{3}{*}{ Recall } & Linear & $79,91 \%$ & $62,25 \%$ & $57,82 \%$ & $85,07 \%$ & $60,27 \%$ \\
\cline { 2 - 7 } & Polynomial & $81,16 \%$ & $63,27 \%$ & $56,59 \%$ & $86,07 \%$ & $60,30 \%$ \\
\cline { 2 - 7 } & Gaussian & $43,21 \%$ & $93,56 \%$ & $13,43 \%$ & $24,10 \%$ & $31,07 \%$ \\
\hline
\end{tabular}

7. Hasil Pengujian Keseluruhan Fold

Pada tahap ini menjelaskan hasil rata-rata klasifikasi terhadap seluruh fold yang digunakan. Proses ini telah melalui ekstraksi fitur LBP dan klasifikasi SVM multiclass. Klasifikasi menggunakan SVM dengan fungsi kernel linear, polynomial dan gaussian. Hasil pengujian berupa nilai rata-rata accuracy, precision dan recall yang dapat dilihat pada Tabel 9 sampai dengan Tabel 11.

Tabel 9. Hasil Accuracy Keseluruhan Fold

\begin{tabular}{|c|c|c|c|c|}
\hline \multirow{2}{*}{ No } & \multirow{2}{*}{ Pengujian } & \multicolumn{3}{|c|}{ Accuracy } \\
\cline { 3 - 5 } & & Linear (\%) & Polynomial (\%) & Gaussian (\%) \\
\hline 1 & 5 -Fold & $86,80 \%$ & $87,59 \%$ & $76,32 \%$ \\
\hline 2 & 6 -Fold & $86,72 \%$ & $87,69 \%$ & $76,81 \%$ \\
\hline 3 & $7-$ Fold & $87,25 \%$ & $88,09 \%$ & $76,40 \%$ \\
\hline 4 & 8 -Fold & $87,13 \%$ & $87,73 \%$ & $76,69 \%$ \\
\hline 5 & $9-$ Fold & $87,34 \%$ & $88,01 \%$ & $76,55 \%$ \\
\hline 6 & 10 -Fold & $87,63 \%$ & $87,79 \%$ & $76,42 \%$ \\
\hline
\end{tabular}

Tabel 10. Hasil Precision Keseluruhan Fold

\begin{tabular}{|c|c|c|c|c|}
\hline \multirow{2}{*}{ No } & \multirow{2}{*}{ Pengujian } & \multicolumn{3}{|c|}{ Precision } \\
\cline { 3 - 5 } & & Linear (\%) & Polynomial (\%) & Gaussian (\%) \\
\hline 1 & 5 -Fold & $67,22 \%$ & $69,14 \%$ & $69,83 \%$ \\
\hline 2 & 6 -Fold & $67,06 \%$ & $69,53 \%$ & $71,30 \%$ \\
\hline 3 & 7 -Fold & $68,81 \%$ & $70,51 \%$ & $72,40 \%$ \\
\hline 4 & 8 -Fold & $68,25 \%$ & $69,71 \%$ & $71,21 \%$ \\
\hline 5 & 9 -Fold & $68,86 \%$ & $70,37 \%$ & $69,90 \%$ \\
\hline 6 & $10-F o l d$ & $69,55 \%$ & $69,72 \%$ & $69,68 \%$ \\
\hline
\end{tabular}

Leonardo, et., al (Klasifikasi Sampah Daur Ulang Menggunakan Support Vector Machine Dengan Fitur Local Binary Pattern) 
Tabel 11. Hasil Recall Keseluruhan Fold

4.

\begin{tabular}{|c|c|c|c|c|}
\hline \multirow{2}{*}{ No } & \multirow{2}{*}{ Pengujian } & \multicolumn{3}{|c|}{ Precision } \\
\cline { 3 - 5 } & & Linear (\%) & Polynomial (\%) & Gaussian (\%) \\
\hline 1 & 5 -Fold & $67,22 \%$ & $69,14 \%$ & $69,83 \%$ \\
\hline 2 & 6 -Fold & $67,06 \%$ & $69,53 \%$ & $71,30 \%$ \\
\hline 3 & 7 -Fold & $68,81 \%$ & $70,51 \%$ & $72,40 \%$ \\
\hline 4 & 8 -Fold & $68,25 \%$ & $69,71 \%$ & $71,21 \%$ \\
\hline 5 & 9 -Fold & $68,86 \%$ & $70,37 \%$ & $69,90 \%$ \\
\hline 6 & 10 -Fold & $69,55 \%$ & $69,72 \%$ & $69,68 \%$ \\
\hline
\end{tabular}

KESIMPULAN

Penelitian ini melakukan klasifikasi sampah daur ulang jenis cardboard, glass, metal, paper dan plastic dengan menggunakan metode ekstraksi fitur tekstur Local Binary Pattern (LBP) dan klasifikasi Support Vector Machine (SVM) didukung metode untuk pengujian dan pembagian dataset K-Fold Cross Validation jenis Leave One Out (LOO). Berdasarkan penelitian yang telah dilaksanakan terdapat beberapa kesimpulan yang diperoleh yaitu sebagai berikut :

1. Dari hasil pengujian keseluruhan fold pada fungsi kernel linear, polynomial dan Gaussian (Tabel 4.25). Accuracy kernel linear terbaik yaitu 87,63\% dengan menggunakan 10-Fold. Untuk kernel polynomial mendapatkan accuracy tertinggi senilai $88,09 \%$ pada penggunaan 7-Fold. Sedangkan kernel gaussian memperoleh accuracy tertinggi 76,81\% dengan menggunakan 6-Fold.

2. Berdasarkan hasil pengujian klasifikasi SVM baik kernel linear, polynomial maupun Gaussian dengan memakai fold 5 sampai fold 10. Accuracy terbaik jenis sampah cardboard senilai 92,61\% (Tabel 4.3). Untuk jenis sampah glass accuracy terbaik didapat senilai $85,76 \%$ (Tabel 4.5). Selanjutnya jenis sampah metal mendapatkan nilai accuracy terbaik 86,10\% (Tabel 4.5). Kemudian jenis sampah paper nilai accuracy tertinggi sebesar 93,60\% (Tabel 4.3). Serta jenis sampah plastic yang memperoleh nilai accuracy tertinggi $84,42 \%$ (Tabel 4.5). Dari hasil ini maka dapat disimpulkan bahwa pemakaian kernel polynomial mendapatkan hasil accuracy terbaik dengan jenis sampah cardboard, glass, metal dan paper yang dapat dilihat pada Tabel 4.3 dan 4.5. Sedangkan kernel gaussian mendapatkan hasil accuracy terbaik jenis sampah plastic yang dapat dilihat pada Tabel 4.5.

\section{SARAN}

Berdasarkan penelitian yang telah dilakukan, berikut ini adalah beberapa saran yang diberikan untuk arah perkembangan selanjutnya:

1. Melakukan klasifikasi dengan ekstraksi fitur yang berbeda serta mencoba menggunakan fitur gabungan.

2. Mencoba untuk melakukan pengujian cross validation dengan fold 3 atau fold 4 .

3. Menambahkan metode segmentasi grabcut untuk mendapatkan kualitas hasil yang diinginkan.

Leonardo, et., al (Klasifikasi Sampah Daur Ulang Menggunakan Support Vector Machine Dengan Fitur Local Binary Pattern) 


\section{DAFTAR PUSTAKA}

[1] Adedeji, O., \& Wang, Z. (2019). Intelligent waste classification system using deep learning convolutional neural network. Procedia Manufacturing, 35, 607-612. https://doi.org/10.1016/j.promfg.2019.05.086

[2] Akmalia, N., Sihombing, P., \& Suherman. (2019). Skin diseases classification using local binary pattern and convolutional neural network. 2019 3rd International Conference on Electrical, Telecommunication and Computer Engineering, ELTICOM 2019 Proceedings, 168-173. https://doi.org/10.1109/ELTICOM47379.2019.8943892

[3] Aral, R. A., Keskin, S. R., Kaya, M., \& Haciömeroğlu, M. (2019). Classification of trashnet dataset based on deep learning models. Proceedings - 2018 IEEE International Conference on Big Data, Big Data 2018, 2058-2062. https://doi.org/10.1109/BigData.2018.8622212

[4] Dhar, P., Chowdhury, M. B. U., \& Biswas, T. (2018). Paper currency detection system based on combined SURF and LBP features. 2018 International Conference on Innovations in Science, Engineering and Technology, ICISET 2018, October, 27-30. https://doi.org/10.1109/ICISET.2018.8745646

[5] Hegenbart, S., \& Uhl, A. (2015). A scale- and orientation-adaptive extension of local binary patterns for texture classification. Pattern Recognition, 48(8), 2633-2644. https://doi.org/10.1016/j.patcog.2015.02.024

[6] Heikkilä, M., Pietikäinen, M., \& Schmid, C. (2009). Description of interest regions with local binary patterns. Pattern Recognition, 42(3), 425-436. https://doi.org/10.1016/j.patcog.2008.08.014

[7] Klyueva, I. (2019). Improving quality of the multiclass SVM classification based on the feature engineering. Proceedings - 2019 1st International Conference on Control Systems, Mathematical Modelling, Automation and Energy Efficiency, SUMMA 2019, 491-494. https://doi.org/10.1109/SUMMA48161.2019.8947599

[8] Long, S. (n.d.). Face recognition based on FP-growth improved LBP operator. 1, 100-103

[9] Manerkar, M. S., Snekhalatha, U., Harsh, S., Saxena, J., Sarma, S. P., \& Anburajan, M. (2016). Automated skin disease segmentation and classification using multi-class SVM classifier. IET Conference Publications, 2016(CP739). https://doi.org/10.1049/cp.2016.1528

[10] Pitria, P. (2016). Pengguna twitter pada akun resmi samsung indonesia dengan menggunakan naïve bayes. Informatika, Teknik Komputer, Universitas Bandung, $J$ Dipatiukur

[11] Qiu, S., Gu, S., \& Zhang, T. (2010). Rearsh on paper defects recognition based on SVM. Proceedings - 2010 WASE International Conference on Information Engineering, ICIE 2010, 1, 177-180. https://doi.org/10.1109/ICIE.2010.49

[12] Rosandy, T. (2016). Perbandingan metode naïve bayes classifier dengan metode decision tree (C4.5) untuk menganalisa kelancaran pembiayaan. (Study Kasus: KSPPS / BMT AL-FADHILA. Jurnal Teknologi Informasi Magister Darmajaya, 2(01), 5262

[13] Verma, A. K., Pal, S., \& Kumar, S. (2019). Classification of skin disease using ensemble data mining techniques. Asian Pacific Journal of Cancer Prevention, 20(6), 18871894. https://doi.org/10.31557/APJCP.2019.20.6.1887

[14] Wong, T. T. (2015). Performance evaluation of classification algorithms by k-fold and leave-one-out cross validation. Pattern Recognition, 48(9), 2839-2846. https://doi.org/10.1016/j.patcog.2015.03.009

[15] Xiong, Z., Cui, Y., Liu, Z., Zhao, Y., Hu, M., \& Hu, J. (2020). Evaluating explorative prediction power of machine learning algorithms for materials discovery using kfold forward cross-validation. Computational Materials Science, 171(August 2019), 109203. https://doi.org/10.1016/j.commatsci.2019.109203

Leonardo, et., al (Klasifikasi Sampah Daur Ulang Menggunakan Support Vector Machine Dengan Fitur Local Binary Pattern) 
[16] Yadav, S., \& Shukla, S. (2016). Analysis of k-fold cross-validation over hold-out validation on colossal datasets for quality classification. Proceedings - 6th International Advanced Computing Conference, IACC 2016, Cv, 78-83. https://doi.org/10.1109/IACC.2016.25

[17] Yang, M., \& Thung, G. (2016). Classification of trash for recyclability status. 1-6. https://doi.org/10.1145/2971648.2971731

Leonardo, et., al (Klasifikasi Sampah Daur Ulang Menggunakan Support Vector Machine Dengan Fitur Local Binary Pattern) 